\title{
Organic Matter Degradation in Lobster Culture System and Their Effect on Waters Quality in Ekas Bay, Indonesia
}

\author{
Muhammad Junaidi (Corresponding author) \\ Study Program of Aquaculture, Mataram University, Indonesia \\ Tel: 62-370-633-007. E-mail: junaidi_md@yahoo.co.id
}

\begin{abstract}
Sri Andayani
Faculty of Fisheres and Marine Science, Brawijaya University, Indonesia
\end{abstract}

Tel: 62-341-553-512. Fax: 62-341-55-7837

Muhamad Mahmudi

Faculty of Fisheries and Marine Science, Brawijaya University, Indonesia

Tel: 62-341-553-512. Fax: 62-341-557-837

Aida Sartimbul

Faculty of Fisheries and Marine Science, Brawijaya University, Indonesia

Tel: 62-341-553-512. Fax: 62-341-557-837

Received: December 29, 2013 Accepted: January 22, 2014 Published: February 14, 2014

Doi: 10.5296/jab.v2i1.5108 URL: http://dx.doi.org/jab.v2i1.5108

\begin{abstract}
Feed degradation testing was carried out by feed incubation placed in nylon bags sunk in the sea for 50 days. During incubation was done the content analysis of C, N and P of feed periodicly. Waters quality determination of Ekas Bay was carried out by using STORET system. The result showed that feed decomposition rate was quickly occurred until the twenty ninth period of incubation, then continued to be slowly with the composition rate constant of
\end{abstract}




\section{Macrothink}

$\mathrm{k}_{1}$ and $\mathrm{k}_{2}$ found to be 0.043 and 0.026 , respectively. Nutrient releasing (dried weight/day) of $\mathrm{C}, \mathrm{N}$ and $\mathrm{P}$ of feed was $0.326 \mathrm{C} / \mathrm{g}, 0.177 \mathrm{~N} / \mathrm{g}$ and $0.073 \mathrm{P} / \mathrm{g}$, respectively. Waters quality status of Ekas Bay was in $\mathrm{C}$ class (moderate fouled) with standard quality over parameters were ammoniac $(0.3 \mathrm{mg} / \mathrm{L})$, nitrate $(0.008 \mathrm{mg} / \mathrm{L})$ and phosphate $(0.015 \mathrm{mg} / \mathrm{L})$. Therefore, to anticipate the availability decreasing of habitat and its effect on culture aquatic environment is need to search efforts which can decrease waste removal rate of ammoniac, nitrate and phosphate to culture environment to minimize the effect of culture activity.

Keywords: Degradation, Nutrient releasing, Feed, Water quality, Organic matter, Ekas Bay 


\section{Introduction}

Marine culture development in Indonesia is very prospective because it is a maritime country with the coastal line length about $81000 \mathrm{~km}$. The potential waters wide for marine culture is estimated ha 12.14 million. From that, it has just been used about $0.01 \%$ (Nurdjana, 2006). One of waters areas which has the potential to be developed as marine culture is Ekas Bay, West Nusa Tenggara Province. Ekas Bay located in South part of Lombok Island has a characteristic because it directly faced with Hindia Ocean and near to Alas Straits, which connected water mass from Hindia Ocean to Pasific Ocean causing it hold more nutrient supply (Marine and Fishery Research Agency, 2004).

In Ekas Bay, Lobster culture has been developed in floating net cage since 2000. It was proved by more post larvae and larvae of lobster found to naturally stick on seaweed culture substrate and grouper (Priyambodo \& Sarifin, 2009; Jones et al., 2010; Jones, 2010). In recent years, more than a hundred floating net cages have been built by the society in Ekas Bay. It indicated that floating net cage (FNC) system culture has been the economic matters prime mover of coastal society to substitute fishery capture. Therefore, it is continuously need a floating net cage culture management to support the development of Ekas Bay as aqua industry area which has a base of FNC culture.

FNC lobster culture in Ekas Bay fully has used trash fish as feed. Although trash fish has a cheaper price, it give a negative effect on culture environment namely; has the higher waste residue than formulated feed (Hansen et al., 1990; Chu, 2000, result in $\mathrm{N}$ loading as much as higher 17 times than formulated feed (Chu, 2000) and has the wider effect spreading (Wuet al.,1994). As a comparison, trash fish fed to grouper only about $82 \%$ eaten and the rest would be removed into waters environment (Noor, 2009). The accumulation of feed residue, feces and the other culture wastes will be decomposition and nutrient releasing. It is estimated $75-85 \% \mathrm{C}, 40-80 \% \mathrm{~N}$ and $65-73 \% \mathrm{P}$ which entered into culture system will be lost to aquatic environment causing water pollution and sediment (Talbot \& Hole, 1994; Wu, 1995). Intensive culture and nutrient enrichment were reported to give the potential effect on water quality change (Philips et al., 1993; Boyd, 1999). The high environmental effect of culture using floating net cage system is depended on the size of floating net cage unit, fish density, floating net cage operation time period in the culture area, biophysical condition, waters oceanography, biota which lives in the culture area, and assimilation capacity of culture environment (Milewski, 2001). Besides, Chu (2000) reported that effect of the trash fish use as feed will result in $\mathrm{N}$ loading higher 17 times than formulated feed use.

Based on those data above, this study aims to analyze degradation rate and organic materials releasing in feed of lobster culture system and their effect on the quality of aquatic environment. This study is hoped to give the benefits in culture environment management particularly in environment fouling prevention to support the development of Ekas Bay as FNC culture-based aqua industry area.

\section{Materials and Methods}

\subsection{Feed Degradation Testing}

Feed degradation testing of trash fish was based on method described by Van Rijn and Nussinovitch (1997) and Rachmansyah (2004). Test feed was incubated by using nylon bags 
sink into the waters of floating net cage located in Ekas Bay (Figure 1) for 50 days. Prior to incubation, test feed was dried using oven at temperature $60{ }^{\circ} \mathrm{C}$ for 24 hours to stabilize water quality. After dried, feed was weighed to get the constant dry weight and analyzed its $\mathrm{N}, \mathrm{P}$ and $\mathrm{C}$ content by using Kjedahl, Bray-l and Walkley Black method, respectively.

Decomposition rate and nutrient releasing observation of feed were done by using steps as followed (1) prepared 30 nylon bags with the size of $10 \times 10 \mathrm{~cm}$, then each bag was filled 15 $\mathrm{g}$ dried feed and the bags top were bound. The thirty nylon bags were entered into the net bag with the size of $60 \times 30 \mathrm{~cm}$ and its top was also bound. (2) The net bag contained 30 nylon bags of feed was incubated into aquatic by binding to the floating net cage frame of lobster culture for 50 days. On the first fifteen days of incubation period, 3 nylon bags of samples were taken out every three-day and the next fifteen days period until on the day 50, 3 nylon bags of samples were taken out every seven-day. All taken bags were washed with fresh water, dried in oven at temperature of $105^{\circ} \mathrm{C}$ for 24 hours and weighed as well as analyzed their $\mathrm{N}$, $\mathrm{P}$ and $\mathrm{C}$ content.

Component in feed was consisted of labile component which can be quickly degraded and recalcitrant component which can be slowly degraded (Van Rijn et al., 1995; Van Rijn et al., 1997). By using the first orde kinetic (Avnimelech, 1984; Van Rijn et al., 1995; van Rijn et al., 1997), decomposition rate constant for the two components was determined by the equation as followed:

$$
\mathrm{C}=\mathrm{C}_{\mathrm{o}} * \mathrm{e}^{-\mathrm{kt}}
$$

Note: $\mathrm{C}=$ Organic material concentration in $\mathrm{t}$ time; $\mathrm{Co}=$ Organic material concentration in the initial of study $(\mathrm{t}=0)$, and $\mathrm{k}=$ decomposition rate constant. Therefore, feed degradation can be described in two steps following the equation:

$$
\mathrm{D}=100-100\left[\mathrm{~S} * \mathrm{e}^{\mathrm{k}_{1} \mathrm{t}}+(1-\mathrm{S}) * \mathrm{e}^{\mathrm{k}_{2} \mathrm{t}}\right]
$$

Note: $\mathrm{D}=$ decomposition rate (\% of the initial concentration); $\mathrm{S}=$ the initial proportion of labile material, $(1-\mathrm{S})=$ the initial proportion of recalcitrant material; $\mathrm{k}_{1}=$ decomposition rate constant for labile material and $\mathrm{k}_{2}=$ decomposition rate constant for recalcitrant material. 


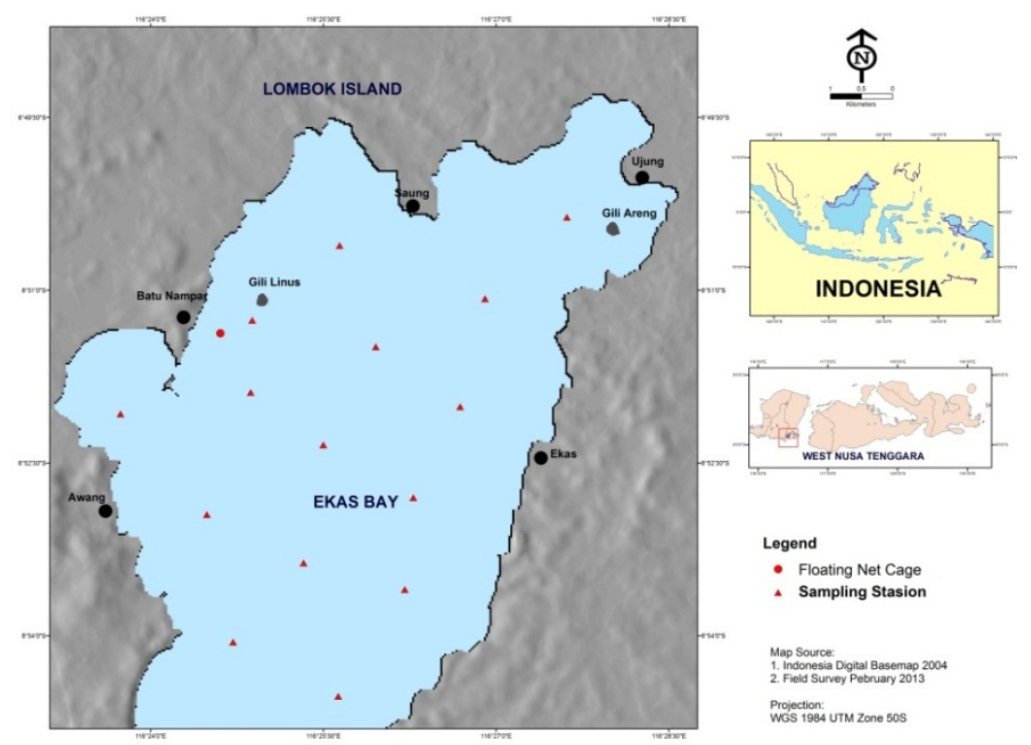

Figure 1. Study location in Ekas Bay, West Nusa Tenggara Province

Feed nutrient releasing of fish was almost similar to nutrient releasing of mangrove leaves manure namely following the equation described by Nga et al. (2004) and Mahmudi (2010) as followed:

$$
\mathrm{NR}=\mathrm{DW}_{0} * \mathrm{~N}_{0}-\mathrm{DW}_{\mathrm{t}} * \mathrm{~N}_{\mathrm{t}}
$$

Note: $\mathrm{NR}=$ nutrient releasing $\left(\mathrm{g} \cdot \mathrm{g}^{-1} \cdot \mathrm{d}^{-1}\right), \mathrm{DW}_{0}=$ the initial dry weight of feed; $\mathrm{DW}_{\mathrm{t}}=$ dry weight of feed rest in the $t$ time (day), $\mathrm{N}_{0}=$ the initial nutrient content, and $\mathrm{N}_{\mathrm{t}}=$ nutrient content in $\mathrm{t}$ time

\subsection{Quality Status Determination of Ekas Bay Waters}

Determination of water quality was obtained through in-situ measurement in field and ex-situ in laboratory at 15 observation stations (Figure 1). Monitoring of stations was done by using GPS. Data collection was carried out by doing in-situ measurement in the field on water quality parameters such as temperature and dissolved oxygen, salinity, $\mathrm{pH}$, and waters brightness using DO meter, refractometer, $\mathrm{pH}$ meter, and secchi disc, respectively. Meanwhile, ammoniac $\left(\mathrm{NH}_{3}-\mathrm{N}\right)$, nitrate $\left(\mathrm{NO}_{2}-\mathrm{N}\right)$ and phosphate $\left(\mathrm{PO}_{4}\right)$ were analyzed ex-situ in the laboratory. In this study, analysis of water quality parameters was based on APHA (1992) method.

To determine characteristic spatial spreading of water quality among stations was used fold parameter investigation approach based on Principle Component Analysis, PCA) (Soedibjo, 2008; Abdi \& Williams, 2010). The final result of PCA was the presence of similarity or difference of spreading spatial parameters among observation stations. Principle component analysis used program of software XLSTAT 2013.5.09.

Status determination of Ekas Bay waters quality was done by using STOrage and RETrieval (STORET) method (http://www.epa.gov/storet/dbtop.html). STORET method principle was comparison between water quality data and water quality standard adjusted with its proposed to determine water quality status. Every observed parameter was counted its maximum, 
minimum and average values then, compared to quality standard value and given score. Score giving was based on Table 1. After each parameter had score value, value of the all parameters (physical, chemical and biological) was counted and compared to water quality classification based on United States Environmental Protection Agency (US-EPA) as followed: A class (very good), if score $=0, \mathrm{~B}$ class (good), if score $=-1$ to -10 ), $\mathrm{C}$ class (moderate), if score $=-11$ to -21 , and D class (bad), if score $=>-31$.

Table 1. Value system determination to measure water quality status

\begin{tabular}{lllll}
\hline \multirow{2}{*}{$\begin{array}{l}\text { Sample } \\
\text { number }\end{array}$} & Value & Parameter & \\
\cline { 3 - 5 } & & Physical & Chemical & Biological \\
\hline$<10$ & Maximum & -1 & -2 & -3 \\
& Minimum & -1 & -2 & -3 \\
& Average & -3 & -6 & -9 \\
\multirow{2}{*}{10} & Maximum & -2 & -4 & -6 \\
& Minimum & -2 & -4 & -6 \\
& Average & -6 & -12 & -18 \\
\hline
\end{tabular}

Source: Ministry of Live Environment (2003).

\section{Results and Discussions}

\subsection{Feed Degradation}

Feed degradation incubated for 50 days in sea waters with salinity of 32-34 ppt and temperature of $29-30{ }^{\circ} \mathrm{C}$ followed logarithmic model (Figure 2). Based on the first orde kinetic model as in the equation (1) was found that decomposition rate constant (k) was obtained to quickly decrease in the initial and slowly decrease in the end of incubation period time. It proved that feed had labile components causing the occurrence of quick degradation and recalcitrant components which were slowly degraded (van Rijn et al., 1995; van Rijn et al.,1997). Labile components degradation in feed was occurred until the twenty ninth of incubation period time, then, continued to slowly decrease (Figure 2). By using the equation (1) and (2), it was obtained $\mathrm{k}_{1}=0.043 ; \mathrm{k}_{2}=0.026 ; \mathrm{S}=0.713$, and $(1-\mathrm{S})=0.287$.

The using of intensive fish culture system in floating net cage has been definite to result in waste of organic materials and nutrients, which were come from undigested feed residue, excretion and feces production (Wu, 1995; Yokoyama et al., 2010). Culture waste entering into aquatic in solid and colloid form was suspension and dissolved (Islam, 2005). Commonly, waste in solid form will precipitate to waters base whilst, the other forms will be in water's hull. If the presence of culture waste is not used by the other aquatic biota, it will be used by microbes. The use and decomposition of organic materials by microbes can be occurred in aerobic and anaerobic condition (Hopkinson Jr., et al., 2002; Mudryk \& Skorczewski, 2006). Rate constant of aerobic decomposition by using the first orde kinetic in fish culture system was ranged from 0.075 to 0.15/day (Boyd, 1973; Avnimelech et al., 1995). 


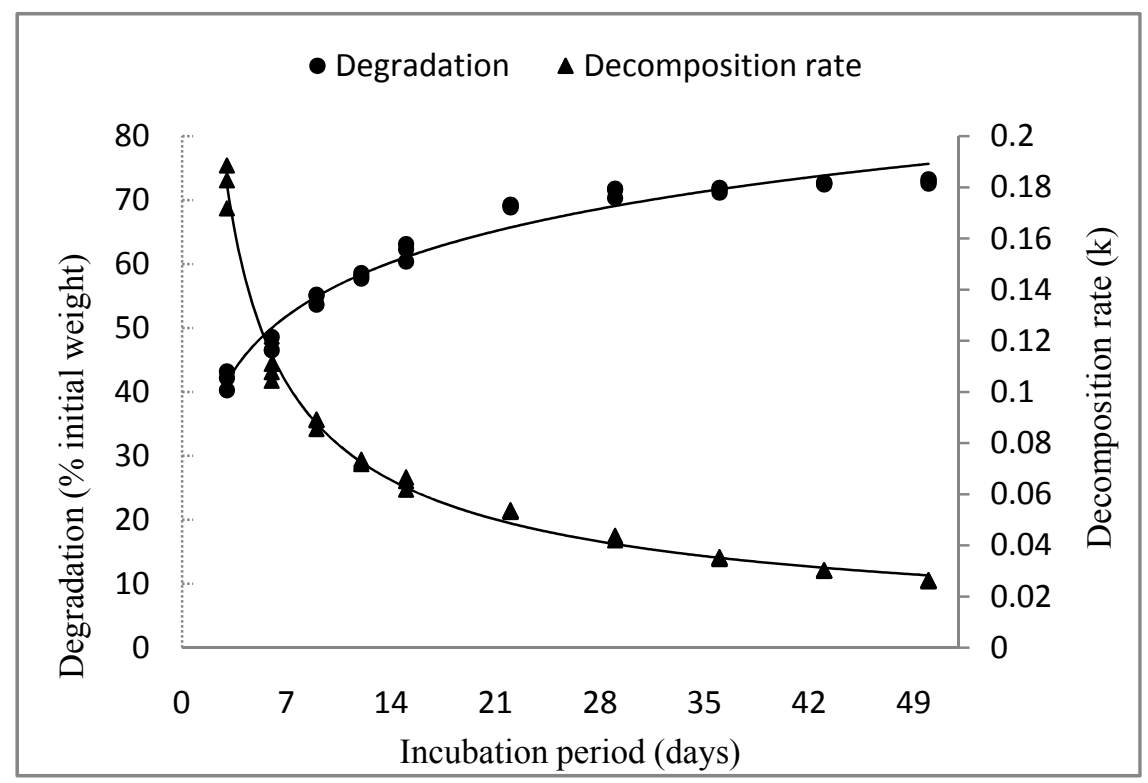

Figure 2. Degradation and decomposition rate constant of trash fish feed incubated for 50 days in Ekas Bay waters with the salinity of 32-34 ppt and temperature of $29-30{ }^{\circ} \mathrm{C}$

During degradation process, feed incubated for 50 days in sea waters had the decreasing $\mathrm{C}, \mathrm{N}$ and $\mathrm{P}$ content in which up to the fiftieth day of incubation period time, the content of $\mathrm{C}, \mathrm{N}$ and $\mathrm{P}$ was $39 \%, 13 \%$ and $50 \%$, respectively (Figure 3 ). It indicated that during incubation, feed component quickly dispersed was Nitrogen $(\mathrm{N})$ content, followed by carbon (C) and phosphate $(\mathrm{P})$.

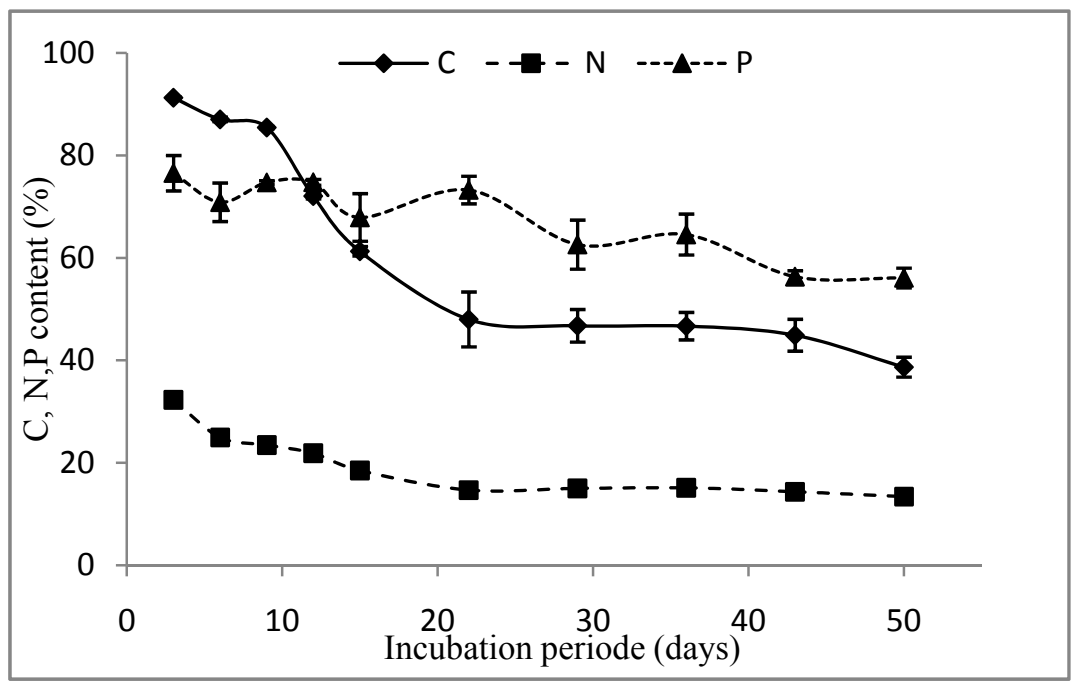

Figure 3. C, N and P content of trash fish feed incubated for 50 days during decomposition process at the salinity of $32-34 \mathrm{ppt}$ and temperature of $29-30{ }^{\circ} \mathrm{C}$

\subsection{Feed Nutrient Releasing}

Based on the Equation (3), it was found feed nutrient releasing incubated for 50 days in sea 
waters at the salinity of $32-34 \mathrm{ppt}$ and temperature of $32-34{ }^{\circ} \mathrm{C}$ were $0.326 \mathrm{~g} \mathrm{C} / \mathrm{g}, 0.177 \mathrm{~g} \mathrm{~N} / \mathrm{g}$ and $0.073 \mathrm{~g} \mathrm{P} / \mathrm{g}$ of dried feed weight per day, respectively. To determine the relation pattern between nutrient releasing and incubation time was done the regression analysis with determination coefficient estimation parameter $\left(\mathrm{R}^{2}\right)$. Regression analysis result showed that regression line of relation between feed nutrient releasing $(\mathrm{C}, \mathrm{N}$ and $\mathrm{P})$ and incubation time was all the three nutrients following logarithm model (Figure 4).

Culture waste load removed into waters hull gave organic material contribution causingnutrient enrichment (hypernutrification) and the organic material which influencedeutrofication and waterquality suitability on culture fish life. Previously, intensive culture and nutrient enrichment were reported to result in potential effect on water quality change (Philips et al., 1993; Boyd, 1999; Alongi, 2003; Alongi, 2009). Therefore, to determine the influence of culture waste load particularly feed residue removed into waters hull, the analysis of Ekas Bay waters quality was carried out.

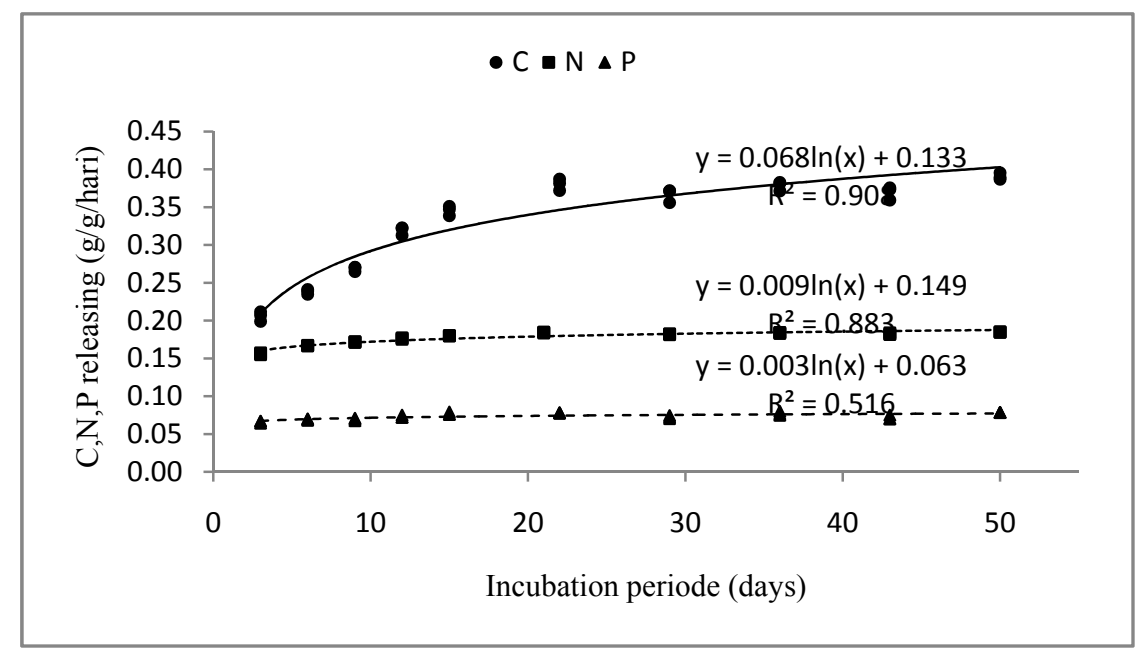

Figure 4. C, N and P releasing of trash fish feed incubated for 50 days at the salinity of 32-34 ppt and temperature of $29-30{ }^{\circ} \mathrm{C}$

\subsection{Water Quality Status of Ekas Bay Waters}

Based on PCA analysis, variety of water quality parameter on the main axis the first, the second, the third and the fourth was $83.03 \%$. It means that $83.03 \%$ of analysis results data can be explained until the fourth main axis. Nevertheless, only the first (F1) and the second main component (F2) were used in the analysis interpretation. On the first axis, DO and ammoniac parameters gave the big contribution to forming of the first main axis. Temperature, ammoniac, DO, and salinity parameters showed negative correlation to nitrate, phosphate, $\mathrm{pH}$, and nitrite parameters. In addition, temperature, nitrate and $\mathrm{pH}$ parameters had the big contribution on the forming of the second main axis(Figure 5a). Spreading of observation station on the first (F1) and the second (F2) axis (Figure 5b) displayed that every station spread evenly. It was due to the difference of water quality parameter identifier. 

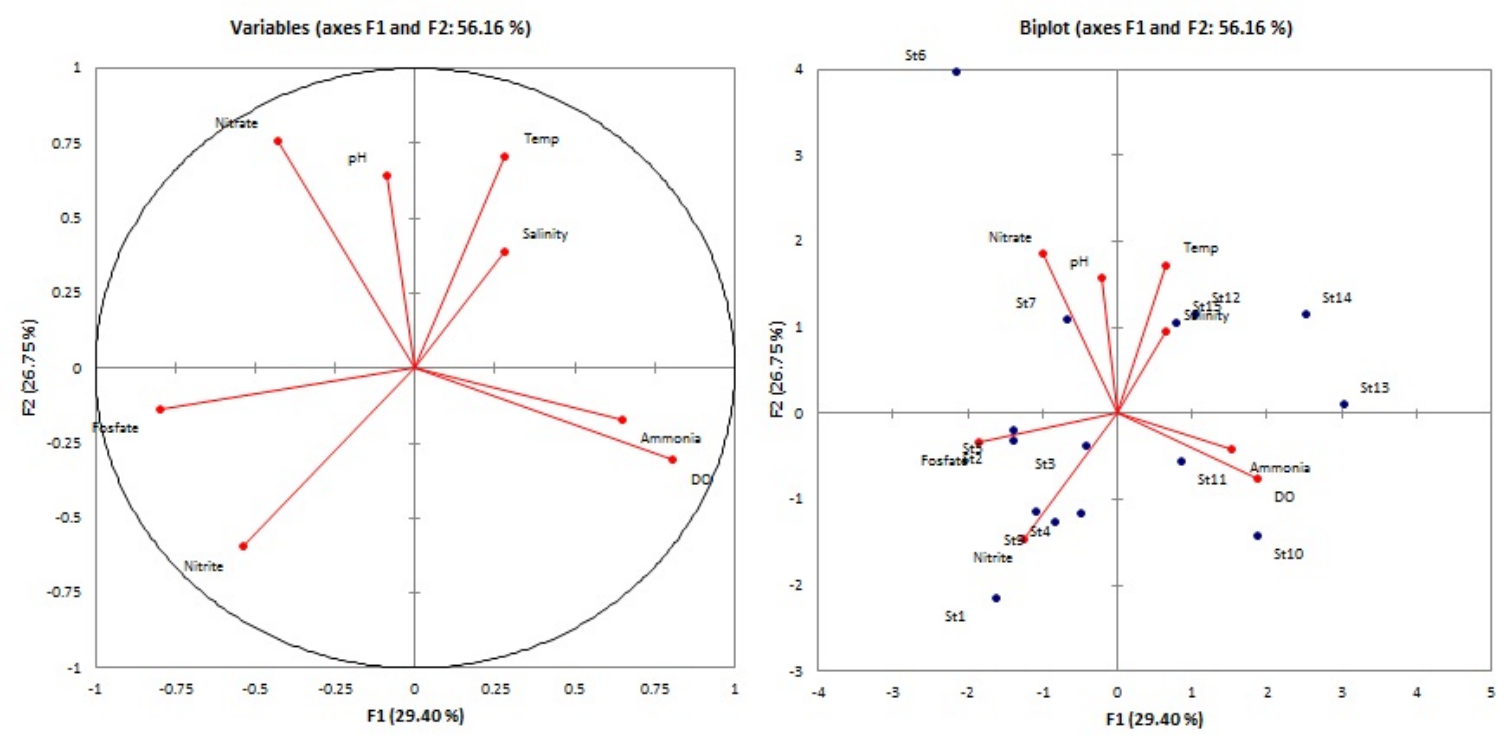

Figure 5. PCA of water quality in Ekas Bay: (a) Ordination of water quality parameter and(b) ordination of observation station

Physical and chemical parameters observation result and waters quality status determination with STORET method are list in Table 2. From Table 2, it was obtained score of -26. Based on value system of US-EPA, quality status of Ekas Bay waters was in C class (moderate fouled). Water quality parameterswith standard quality over parameters were ammoniac $(0.3$ $\mathrm{mg} / \mathrm{L})$, nitrate $(0.008 \mathrm{mg} / \mathrm{L})$ and phosphate $(0.015 \mathrm{mg} / \mathrm{L})$. The similar results were also reported by Krisanti and Imran (2006). Due to the concentration of ammoniac and nitrate which was over quality standard, there was no supporting to develop culture activity in Ekas Bay. Nevertheless, observation on waters fertility level showed that Ekas Bay has not been characterized as fertile waters and will cause the occurrence of plankton blooming or has not been reached waters condition lacking of oxygen. It means that there can be still developedfishery culture activity by using responsible and continuous culture method.

To anticipate the decreasing of habitat suitability and its effect on culture aquatic environment, it needs to search the efforts which can decrease waste removing to culture environment. It is done to minimize the effect of culture activity in Ekas Bay waters.Efforts which can be carried out to decrease fish culture waste load in waters are (1)arrangement by restriction of trash fish feed use, (2) feed efficiency through a good feed giving technique (frequency and appropriate feed dosage) to decrease uneaten feed residue and (3) the use and selection of feed raw material with the high digestible level. 
Table 2. Quality status determination of Ekas Bay water with STORET method

\begin{tabular}{|c|c|c|c|c|c|c|c|}
\hline \multirow[b]{2}{*}{ No } & \multirow[b]{2}{*}{ Parameter } & \multirow[b]{2}{*}{ Unit } & \multirow[b]{2}{*}{$\begin{array}{l}\text { Qualitysta } \\
\text { ndard*) }^{*}\end{array}$} & \multicolumn{3}{|l|}{ Result } & \multirow[b]{2}{*}{ Score } \\
\hline & & & & $\begin{array}{l}\text { Maxi-m } \\
\text { um }\end{array}$ & $\begin{array}{l}\text { Mini-mu } \\
\mathrm{m}\end{array}$ & Average & \\
\hline & Physical & & & & & & \\
\hline 1 & Temperature & $\left({ }^{\circ} \mathrm{C}\right)$ & Natural & 32.6 & 29.6 & 31.2 & 0 \\
\hline \multirow[t]{2}{*}{2} & Brightness & M & $>3$ & 14.3 & 3 & 6.6 & 0 \\
\hline & Chemical & & & & & & \\
\hline 3 & Salinity & $\mathrm{o} / \mathrm{oo}$ & Natural & 35 & 34 & 34.9 & 0 \\
\hline 4 & DO & $\mathrm{mg} / \mathrm{l}$ & $>5$ & 9.8 & 8 & 9.2 & 0 \\
\hline 5 & $\mathrm{pH}$ & & $7-8.5$ & 8.21 & 7.89 & 8.07 & 0 \\
\hline 6 & $\begin{array}{l}\text { Ammoniac } \\
\mathrm{NH}_{3}-\mathrm{N}\end{array}$ & , $\mathrm{mg} / \mathrm{l}$ & 0.3 & 0.484 & 0.283 & 0.344 & -8 \\
\hline 7 & $\begin{array}{l}\text { Nitrite, } \\
\mathrm{NO}_{2}-\mathrm{N}\end{array}$ & $\mathrm{mg} / \mathrm{l}$ & & 0.1 & 0 & 0.042 & \\
\hline 8 & $\begin{array}{l}\text { Nitrate, } \\
\mathrm{NO}_{3}-\mathrm{N}\end{array}$ & $\mathrm{mg} / 1$ & 0.008 & 4.1 & 0.4 & 1.573 & -10 \\
\hline 9 & $\begin{array}{l}\text { Phosphate, } \\
\mathrm{PO}_{4}\end{array}$ & $\mathrm{mg} / \mathrm{l}$ & 0.015 & 0.42 & 0 & 0.221 & -8 \\
\hline & Score total & & & & & & -26 \\
\hline
\end{tabular}

Note : *) Environment minister decision no. 512004.

The other strategies which need to be applied in continuous marine culture development in Ekas Bay waters arethe development of integrated marine farming andallocating of culture resource as well as aquainput in suitable location and no overwater environment supporting ability. These efforts are hoped to be able to give the opportunity on culture business continuity. Therefore, carrying capacity of physical, production, social, and ecological must be determined in the development of floating net cage culture based aqua industry.

\section{Conclussions}

Feed degradation was quickly occurred until the twenty ninth incubation period thereafter, continued to decrease slowly with decomposition rate constant, $\mathrm{k}_{1}=0.043$ and $\mathrm{k}_{2}=0.026$. Feed nutrient releasingof $\mathrm{C}, \mathrm{N}$ and $\mathrm{P}$ was $0.326 \mathrm{~g} \mathrm{C} / \mathrm{g}, 0.177 \mathrm{~g} \mathrm{~N} / \mathrm{g}$ and $0.073 \mathrm{~g} \mathrm{P} / \mathrm{g}$ of dried feed weight per day, respectively. Quality status of Ekas Bay waters was in C class (moderate fouled), in which ammoniac, nitrate and phosphate were found to be parameters over quality standard with the dosage of $0.3 \mathrm{mg} / 1,0.008 \mathrm{mg} / \mathrm{l}$ ) and $0.015 \mathrm{mg} / 1$.To anticipate the decrease of habitat suitability and its effect on culture waters environment is need to search efforts which are able to decrease waste removing rate of feed $\mathrm{C}, \mathrm{N}$ and $\mathrm{P}$ to culture environment. These efforts is hoped to be able to minimize culture activity effect in Ekas Bay waters. 


\section{Acknowledgements}

The Authors thanked to Director of Marine Culture Center, Lombok for the help in the analysis of water quality, and Staffs of Aquaculture Department, MataramUniversity for the support in the writing of this paper.

\section{References}

Abdi, H., \& Williams, L. J. (2010). Principal component analysis. Wiley Inter. Reviews: Computational Statistics, 2, 47.

Alongi, D. M., Chong, V. C., Dixon, P., Sasekumar, A., \& Tirendi. F. (2003). The influence of fish cage aquaculture on pelagic carbon flow and water chemistry in tidally dominated mangrove estuaries of peninsular Malaysia. Mar. Environ. Res, 55, 313-333. http://dx.doi.org/10.1016/S0141-1136(02)00276-3

Alongi, D. M., McKinnon, A. D., Brinkman, R., Trott, L. A., Undi, M. C., \& Rachmansyah. (2009). The fate of organic matter derived from small-scale fish cage aquaculture in coastal waters of Sulawesi and Sumatra, Indonesia. Aquaculture, 295, 60-75. http://dx.doi.org/10.1016/j.aquaculture.2009.06.025

American Public Health Association (APHA). (1992). Standart Methods for the Examination of Water and Wastewater. American Public Health Association. Washington, DC. p. 874.

Avnimelech, Y. (1984). Reaction in fish pond sediment as inferred from sediment cores data. In H. Rosenthaland \& S. Sarig (Eds.), Research on Aquacutur. Special Publication No. 8, European Mariculture Society, Bredene, Belgium. pp. 41-54.

Avnimelech, Y., Mozes, N., Diab, S., \& Kochba, M. (1995). Rates of organic carbon and nitrogen degradation in intensive fish pond. Aquaculture, 134, 211-216. http://dx.doi.org/10.1016/0044-8486(95)00063-8

Boyd, C. E. (1999). Management of shrimp ponds to reduce the eutrophication potential of effluents. The Advocate, pp. 12-13.

Chu, J. C. W. (2000). Enviromental management of marinculture: the effectof feed type on feed waste. RegionalWorkshop on Sustainable Seafarming and Grouper Aquaculture. Collaborative APEC Grouper Research and Development Network (FWG 01/99). Medan 17-20 April 2000.

Environmental ministry. (2003). Minister of environment Decision No. 1152003 about Water Quality Status Determination Guidelines. Environmental ministry of Republic of Indonesia. Jakarta.

Environmental Ministry. (2004). Minister of environment Decision No. 512004 about sea water quality standard.Environmental ministry of Republic of Indonesia. Jakarta.

Hansen, P. K., Pittman, K., \& Ervik, A. (1990). Effects of organic waste from marine fish farms on the seabottom beneath the cages. International Council for the Exploration of the Sea. p. 9. 
Hopkinson Jr. C. S., Vallino, J. J., \& Nolin, A. (2002). Decomposition of dissolved organic matter from the continental margin. Deep-Sea Research II, 49, 4461-4478. http://dx.doi.org/10.1016/S0967-0645(02)00125-X

Howarth, R. W., \& Marino, R. (2006). Nitrogen as the limiting nutrient for eutrophication in coastal marine ecosystems: Evolving views over three decades. Limnol. Oceanogr, 5, 364-376. http://dx.doi.org/10.4319/1o.2006.51.1_part_2.0364

Hudson, J. J, Taylor, W. D. \& Schindler, D. W. (2000). Phosphate concentration in Lake. Nature, 406, 54-56. http://dx.doi.org/10.1038/35017531

Islam, S. Md. (2005). Nitrogen and phosphorus budget in coastal and marine cage aquaculture and impacts of effluent loading on ecosystem: review and analysis towards model development. Marine Pollution Bulletin, $\quad$ 50, http://dx.doi.org/10.1016/j.marpolbul.2004.08.008

Jones, C. M. (2010). Tropical spiny lobster aquaculture development in Vietnam, Indonesia and Australia. J. Mar. Biol. Ass. India, 52(2), 304-315.

Jones, C. M., Long, N. V., Hoc, D. T., \& Priyambodo, B. (2010). Exploitation of puerulus settlement for the development of tropical spiny lobster aquaculture in the Indo-West Pacific. J. Mar. Biol. Ass. India, 52(2), 304-315.

Krisanti, M., \& Imran, Z. (2006). Ekas Bay Waters Environment Carrying Capacityfor Development of Grouper Culture Activity in Floating Net Cage. J. Il.Perta.Indon, 11(2), $15-20$.

Mahmudi, M., (2010). Estimation of fish production through manure nutrient of mangrove leaves in RhizophoraReafforestation Area, Nguling, Pasuruan, East Java. Jawa Oceanography, 15(4), 231-235.

Marine and Fisheries Research Agency. (2004). Marine and fisheries Carrying Capacity. Project team Carrying Capacity of marine and Fishery Research Agency of the Department of marine and fisheries. Jakarta.

Milewski, I. (2001). Impacts of salmon aquaculture on the coastal environment: A Review. Proceedings of a Workshop "Marine aquaculture and the environment: a meeting for stakeholders in the Northeast" held January 11 - 13, 2001 at the University of Massachusetts Boston, USA.

Mudryk, Z. J., and Skorczewski, P. (2006). Enzyamatic activity and degradation of organic macromoleculer by neustonic and planktonic bacteria in an estuarine lake. Pol. J. Ecol., 54(1), 3-14.

Nga, B. T., Tam, D. T., Schaffer, M., \& Roijackers, R. (2004). The decomposition and nutrient release of Rhizophora apiculata leaves in the Camau Province, Mekong Delta, Vietnam. In B. T. Nga (Ed.). Penaeus monodon post-larvae and their interaction with Rhizophora apiculata. Wageningen Universiteit. 
Noor, A. (2009). Environment quality management model based on carrying capacity of bay waters for the development of floating net cage based grouper culture (Case study in Tamiang Bay, Kotabaru Regency, SouthKalimantan province). Ph. D Thesis.Bogor Agriculture Institute (Unpublished).

Nurdjana, M. L. (2006). Indonesia Aquaculture Development. Paper presented at the RCA International Workshop on Innovative Technologies for Eco-Friendly Fish Farm Management and Production of Safe Aquaculture Food, Bali.

Phillips , M. J., Clarke, R., \& Mowat, A. (1993). Phosphorous leaching from Atlantic Salmon diets. Aquaculture Engineering, 12, 47-54. http://dx.doi.org/10.1016/0144-8609(93)90026-8

Priyambodo, B., \& Sarifin. (2009). Lobster aquaculture industry in eastern Indonesia: present status and prospects. In K. C. Williams (Ed.), Proceedings of an International Symposium on Spiny Lobster Aquaculture in the Asia-Pacific Region, Australian Centre for International Agricultural Research, Canberra, pp. 36-45.

Rachmansyah. (2004). Analysis of Awarange Waters Environment Carrying Capacity in Barru Regency, South Sulawesi, for the Development of Milk Fish Culture in Floating Net Cage. Ph. D Thesis. Bogor Agriculture Institute. Bogor. Unpublished.

Soedibjo, B. S. (2008). Analysis of the main component in ecological study. Oceana, 33(2), 43-53.

Talbot, C., \& Hole, R. (1994). Fish diets and the control of eutrophication resulting from aquaculture. Journal of Applied Ichthyology, 10(4), 258-270. http://dx.doi.org/10.1111/j.1439-0426.1994.tb00165.x

Van Rijn, J., \&Nussinovitch, A. (1997). An emprical model for predicting degradation of organic solids in fish culture systems based on short-term observations. Aquaculture, 154, 173-179. http://dx.doi.org/10.1016/S0044-8486(97)00048-3

Van Rijn, J., Fonarev, N., \& Berkowitz, B. (1995). Anaerobic treatment of intensive fish culture effleuents: digestion of fish feed and release of volatile fattty acids. Aquaculture, 133, 9-20. http://dx.doi.org/10.1016/0044-8486(94)00386-3

$\mathrm{Wu}, \mathrm{R}$. S. S. (1995). The environmental imapct of marine fish culture: towards a sustainable future. Marine Pollution Bulletin, 31(4-12), 159-166. http://dx.doi.org/10.1016/0025-326X(95)00100-2

Wu, R. S. S., Lam, K. S., MacKey, D. W., Lau, T. C., \& Yam, V. (1994). Impact of marine farming on water quality and bottom sediment: A case study in the sub-tropical environment. Marine Environment Research, 38, 115-145. http://dx.doi.org/10.1016/0141-1136(94)90004-3

Yokoyama, H., Ishihi, Y., Abo, K., \& Takashi, T. (2010). Quantification of waste feed and fish feces using stable carbon and nitrogen isotopes. Bull. Fish. Res. Agen, 31, 71-76. 


\section{Copyright Disclaimer}

Copyright reserved by the author(s).

This article is an open-access article distributed under the terms and conditions of the Creative Commons Attribution license (http://creativecommons.org/licenses/by/3.0/). 